\title{
Acute food deprivation reduces expression of diazepam-binding inhibitor, the precursor of the anorexigenic octadecaneuropeptide ODN, in mouse glial cells
}

\author{
V Compère ${ }^{1,2,3}$, D Lanfray ${ }^{1,2}, \mathrm{H}$ Castel $^{1,2}, \mathrm{~F}$ Morin $^{1,2}, \mathrm{~J} \mathrm{Leprince}^{1,2}$, \\ B Dureuil ${ }^{3}$, H Vaudry ${ }^{1,2}$, G Pelletier ${ }^{4}$ and M C Tonon ${ }^{1,2}$
}

\author{
${ }^{1}$ Inserm U982, Laboratory of Neuronal and Neuroendocrine Communication and Differentiation and ${ }^{2}$ University of Rouen, European Institute for Peptide Research (IFRMP 23), \\ Regional Platform for Cell Imaging of Normandy (PRIMACEN), University of Rouen, 76821 Mont-Saint-Aignan, France \\ ${ }^{3}$ Department of Anesthesiology and Critical Care, Rouen University Hospital, 7600 Rouen, France \\ ${ }^{4}$ Research Center in Molecular Endocrinology, Oncology and Genetics, Laval University Hospital Center, Quebec City, Quebec, Canada G1V4G2
}

(Correspondence should be addressed to M C Tonon at Inserm U982, Laboratory of Neuronal and Neuroendocrine Communication and Differentiation, European Institute for Peptide Research (IFRMP 23), University of Rouen; Email: marie-christine.tonon@univ-rouen.fr)

\begin{abstract}
In the central nervous system of mammals, the gene encoding diazepam-binding inhibitor (DBI) is exclusively expressed in glial cells. Previous studies have shown that central administration of a DBI processing product, the octadecaneuropeptide ODN, causes a marked inhibition of food consumption in rodents. Paradoxically, however, the effect of food restriction on $D B I$ gene expression has never been investigated. Here, we show that in mice, acute fasting dramatically reduces $D B I$ mRNA levels in the hypothalamus and the ependyma bordering the third and lateral ventricles. I.p. injection of insulin, but not of leptin, selectively stimulated DBI expression in the lateral ventricle area. These data support the notion that glial cells, through the production of endozepines, may relay peripheral signals to neurons involved in the central regulation of energy homeostasis.
\end{abstract}

Journal of Molecular Endocrinology (2010) 44, 295-299

\section{Introduction}

Hypothalamic neuropeptide signaling systems play an important role in the control of food intake and energy expenditure in mammals. These systems notably include two interconnected populations of neurons located in the arcuate nucleus (ARC), one producing the orexigenic neuropeptide Y (NPY) and the other one producing the anorexigenic peptide $\alpha$-melanocytestimulating hormone $(\alpha-\mathrm{MSH})$, a processing product of proopiomelanocortin (POMC; Schwartz et al. 2000).

It is now recognized that astroglial cells can release various biologically active molecules, called gliotransmitters, that participate in the regulation of neuronal activity (Volterra \& Meldolesi 2005). In particular, astrocytes express the polypeptide diazepam-binding inhibitor (DBI) which generates through proteolytic cleavage several regulatory peptides including the anorexigenic octadecaneuropeptide (ODN; De Mateos-Verchere et al. 2001, Do Rego et al. 2007, Matsuda et al. 2007). DBI is highly expressed in astroglial cells located in the hypothalamic regions which play a major role in the control of food intake, i.e. the ARC, the dorso- and ventromedial nuclei, and the lateral area of the hypothalamus (Malagon et al. 1993). I.c.v. administration of ODN in rats provokes a reduction of
$N P Y$ mRNA and an increase of POMC mRNA levels (Compère et al. 2003), suggesting that the anorexigenic action of ODN is mediated through inhibition of NPY neurons and/or activation of POMC neurons.

Acute food deprivation causes a reduction in circulating leptin and insulin levels (Bi et al. 2003). During re-feeding, insulin and leptin act as feedback signals stimulating the activity of hypothalamic POMC neurons and inhibiting the activity of NPY neurons (Schwartz et al. 2000).

Although there is clear evidence that the endozepine ODN is a potent anorexigenic peptide (De MateosVerchere et al. 2001, Do Rego et al. 2007, Matsuda et al. 2007), the possible involvement of satiety signals in the control of $D B I$ gene expression has never been reported. Therefore, in the present study, we have examined the effect of food deprivation as well as of insulin and leptin administration on DBI mRNA levels in astroglial cells.

\section{Materials and methods}

The effects of fasting, insulin and leptin administration on $D B I$ mRNA levels were investigated on 12-14-weekold male C57BL/6 mice (Charles River Laboratories, 
St Constant, Quebec, Canada). All animal procedures were approved by the Laval University Animal Welfare Committee.

\section{Treatments}

To study the effect of fasting, 12 mice were divided into two groups. In the control group, mice $(n=6)$ had free access to standard rodent chow and drinking tap water, and in the second group, mice $(n=6)$ had free access to drinking tap water, but were food deprived for $24 \mathrm{~h}$.

To examine the effects of insulin and leptin, 36 mice were food deprived for $24 \mathrm{~h}$. Then, animals were divided into three groups. In the first group, mice $(n=12)$ received an i.p. injection of murine leptin $(100 \mu \mathrm{g} / 0 \cdot 1 \mathrm{ml}$; Sigma $)$. In the second group, mice $(n=12)$ received an i.p. injection of bovine insulin $(0 \cdot 1 \mathrm{UI} / 0 \cdot 1 \mathrm{ml}$; Sigma). In the third group, mice $(n=12)$ received an i.p. injection of vehicle $(5 \mathrm{mM}$ sodium citrate, $\mathrm{pH} 4 \cdot 0 ; 0 \cdot 1 \mathrm{ml}$ ). The effect of treatments on $D B I$ mRNA was analyzed 1 and $4 \mathrm{~h}$ after leptin or insulin administration.

Animals were deeply anesthetized with ketaminexylazine, and were then perfused transcardially with $4 \%$ paraformaldehyde in $0.2 \mathrm{M}$ phosphate buffer. The brains were removed and post-fixed in the same fixative overnight at $4{ }^{\circ} \mathrm{C}$, and were then placed in $0 \cdot 1 \mathrm{M}$ phosphate buffer containing $15 \%$ sucrose overnight at $4{ }^{\circ} \mathrm{C}$. Thereafter, the tissues were frozen on dry ice in a support medium (OCT, Bayer Corp.), and were conserved at $-80^{\circ} \mathrm{C}$ until in situ hybridization and immunohistochemistry experiments.

\section{In situ hybridization}

Frontal brain sections $(10 \mu \mathrm{m})$ were mounted on Superfrost/PLUS microscope slides (Fisher Scientific, Montreal, Quebec, Canada), and were stored at $-80{ }^{\circ} \mathrm{C}$ until use. In situ hybridization was performed as described previously (Compère $e t$ al. 2003). The vector used for the production of the cRNA probe was constructed by insertion of a $266 \mathrm{bp}$ fragment of mouse DBI cDNA (GenBank no. NM_007830, nucleotides 215-461) into pCR-BluntII-TOPO (Invitrogen). After hybridization, the sections were dehydrated and coated with liquid photographic emulsion (Kodak NTB-2), and were exposed for 12 days. Semiquantitative analysis of the hybridization signal was carried out on nuclear emulsion-dipped slides over the reactive cells in the hypothalamus using a Zeiss Optical System coupled to a Macintosh computer (Power PC 7500/100) and the Image Software (version 1.60 non-FPU, W Rasband, NIH, Bethesda, MD, USA). The optical density of the hybridization signal measured in each specific region was corrected for the average background signal. Quantitative data are presented as mean ( \pm s.e.m.) calculated from the measurements obtained from 12 to 18 sections per mouse $(n=6)$ in the same hypothalamic region. Comparison of the mRNA levels between experimental groups was performed by an ANOVA (Statview, Abacus Concepts, Berkeley, CA, USA), and differences were considered significant at $P<0 \cdot 05$. Incubation of brain sections with the sense DBI probe did not produce any detectable labeling.
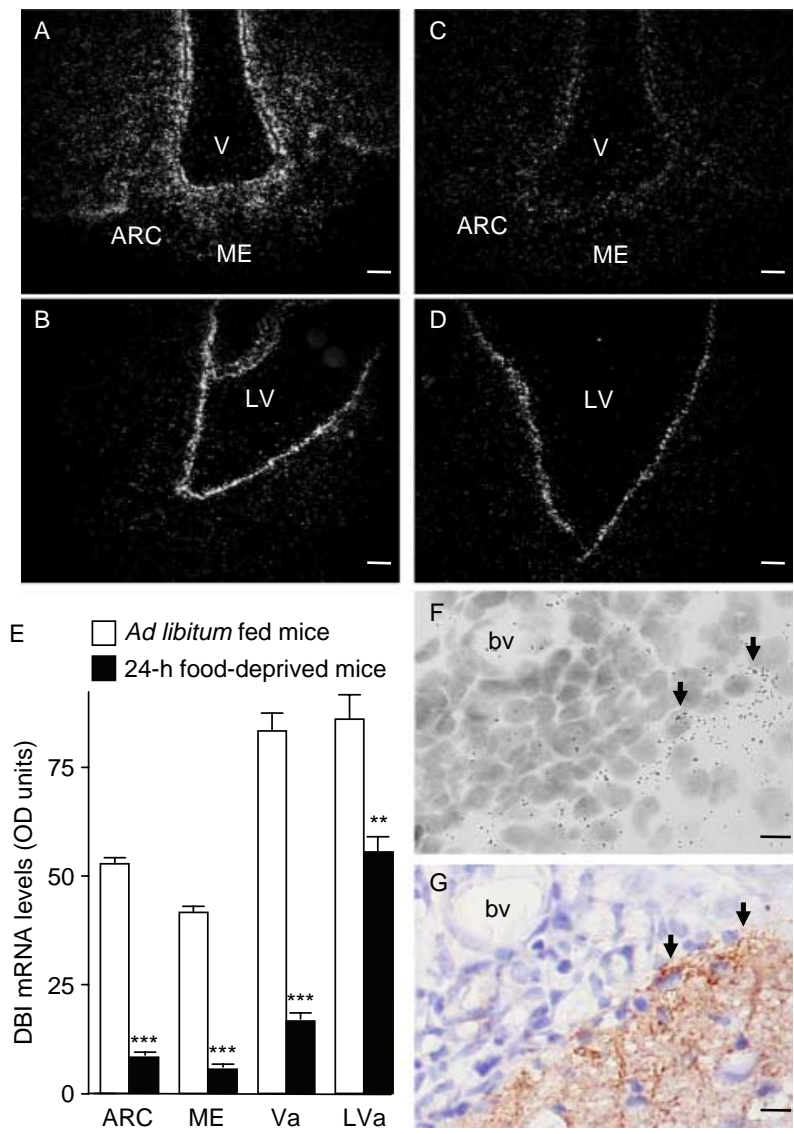

Figure 1 Dark- and bright-field photomicrographs showing the expression of $D B I$ mRNA in the hypothalamus and the lateral ventricle of normally fed and food-deprived mice. Frontal sections through the hypothalamus ( $A$ and $C$ ) and the lateral ventricle ( $B$ and $D$ ) of ad libitum fed ( $A$ and $B$ ) and acute food-deprived mice $(C$ and $\mathrm{D})$ were hybridized with the $\mathrm{DBI}$ antisense riboprobe. The effects of food deprivation on DBI mRNA were quantified by measuring the integrated optical density (OD) of the signal in each area $(\mathrm{E} ; n=6)$. ( $\mathrm{F}$ and $\mathrm{G})$ Brain sections were hybridized with the $\mathrm{DBI}$ antisense riboprobe $(\mathrm{F})$, and adjacent sections were labeled (brown staining) with antibodies against GFAP $(\mathrm{G})$. The arrows point to identified cells expressing $D B I$ mRNA positively stained with GFAP. V, third ventricle; Va, area bordering the third ventricle; ARC, arcuate nucleus; ME, median eminence; LV, lateral ventricle; LVa, area bordering the lateral ventricle; and bv, blood vessel. Scale bars $=250 \mu \mathrm{m}(A-D)$ and $10 \mu \mathrm{m}(F$ and $G)$. ${ }^{\star *} P<0.01,{ }^{* *} P<0.001$ versus controls. Full colour version of this figure available via http://dx.doi.org/10.1677/JME-09-0176. 

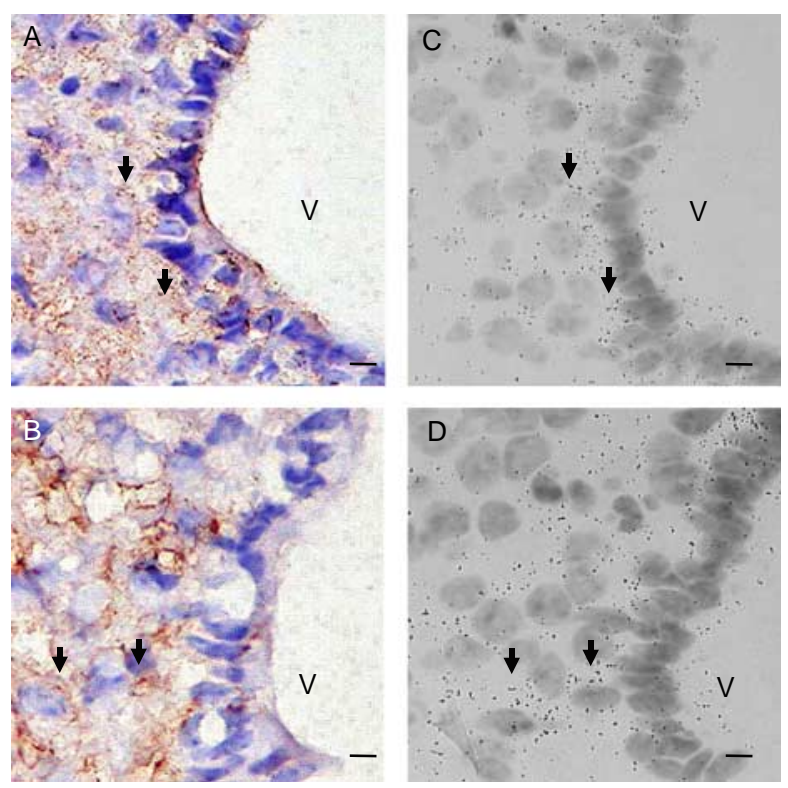

Figure 2 Bright-field photomicrographs showing the presence of insulin and leptin receptors in DBI-expressing cells in the arcuate nucleus of the mouse hypothalamus. Brain sections were labeled (brown staining) with antibodies against insulin receptors $(A)$ or leptin receptors $(B)$, and adjacent sections were hybridized with the $\mathrm{DBI}$ antisense riboprobe $(\mathrm{C}$ and $\mathrm{D})$. The arrows point to identified cells expressing $D B I$ mRNA positively stained with insulin $(A$ and $C$ ) or leptin (B and $D)$ receptors. V, third ventricle. Scale bars $=10 \mu \mathrm{m}$. Full colour version of this figure available via http://dx.doi.org/10.1677/JME-09-0176.

\section{Immunohistochemistry}

Sections adjacent to those used for in situ hybridization were first hydrated, and were then incubated overnight at $4{ }^{\circ} \mathrm{C}$ with a monoclonal antibody raised against mouse leptin receptor (Ob-R; 1:500; sc-8391, Santa Cruz Biotechnology, Santa Cruz, CA, USA), purified polyclonal antibodies raised against the $\beta$-subunit of the insulin receptor $(1: 500$; sc-711, Santa Cruz Biotechnology), or polyclonal antibodies raised against glial fibrillary acidic protein (GFAP; 1:1000; Dako, Glostrup, Denmark). Western blot analysis of mouse tissue/cell extracts indicated that the Ob-R antibody detects two bands corresponding to the long and short forms of Ob-R (sc-8391; Santa Cruz Biotechnology; Magni et al. 1999), and insulin receptor antibodies detect two bands corresponding to the $\beta$-subunit of the insulin receptor and insulin receptor precursor (sc-711; Santa Cruz Biotechnology). Sections were then washed in PBS ( $\mathrm{pH} 7 \cdot 6$ ), incubated at room temperature for $10 \mathrm{~min}$ with the ultra streptavidin-HRP reagent (Signet, Dedham, MA, USA), and stained with 3,3'-diaminobenzidine. Brain sections incubated with phosphate buffer or non-immune serum, instead of with the primary antibodies, did not exhibit any detectable labeling.

\section{Results and discussion}

As previously shown in rats (Tonon et al. 1990), in the mouse brain, the expression of the $D B I$ gene is restricted to astroglial cells notably ependymocytes bordering the third and lateral ventricles, and tanycytes of the median eminence (Fig. $1 \mathrm{~A}$ and $\mathrm{B}$ ), where $D B I$ mRNA colocalized with the astroglial cell marker GFAP (Fig. $1 \mathrm{~F}$ and $\mathrm{G}$ ). The present work demonstrates, for the first time, that food deprivation strongly reduces the level of $D B I$ mRNA in the outer area of the ARC, in the median eminence, and in the area bordering the lateral ventricle (Fig. 1A-E). It has been previously
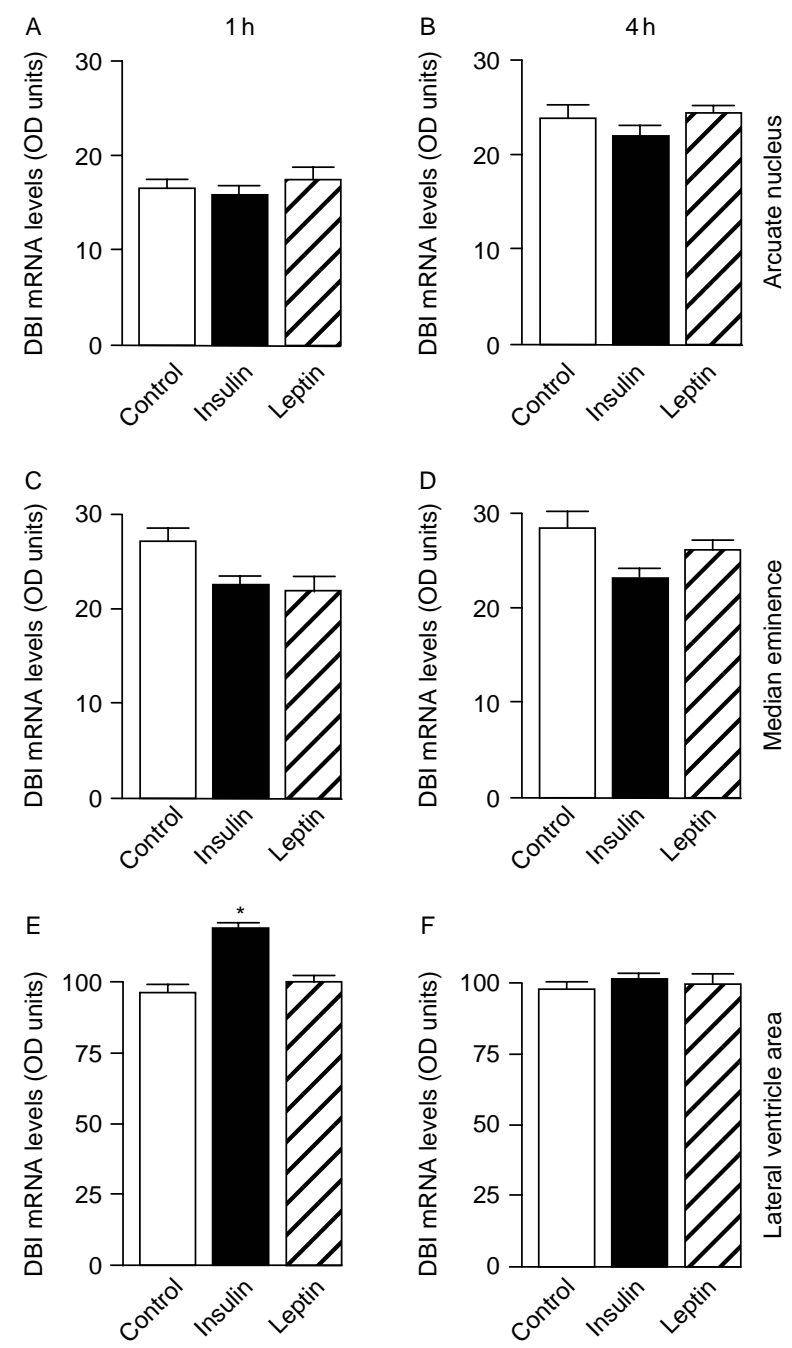

Figure 3 Effects of i.p. injections of insulin or leptin on DBI mRNA levels in food-deprived mice. The in situ hybridization signal was quantified by measuring the integrated optical density (OD) of the signal in each area, i.e. arcuate nucleus ( $A$ and $B)$, median eminence $(C$ and $D)$, and area bordering the lateral ventricle $(E$ and $F)$. The effect of treatment was analyzed $1 \mathrm{~h}(A, C$, and $E)$ and $4 \mathrm{~h}(\mathrm{~B}, \mathrm{D}$, and $\mathrm{F})$ after insulin or leptin administration. ${ }^{\star} P<0.05$ versus controls $(n=6)$. 
demonstrated that food deprivation inhibits central anorexigenic pathways, and notably reduces the expression of POMC and thus the production of the anorexigenic neuropeptide $\alpha-\mathrm{MSH}$ in the hypothalamus (Swart et al. 2002, Bi et al. 2003). The present observation that fasting profoundly inhibits DBI expression in the hypothalamus provides additional support for a physiological role of the anorexigenic DBI-derived peptide ODN in the central control of energy homeostasis.

The two hormones insulin and leptin are known to convey information about the status of body energy stores to the brain (Niswender \& Schwartz 2003, for review), and the hypothalamic POMC or NPY neurons express insulin and leptin receptors (Hakansson et al. 1996, Baskin et al. 1999, Pardini et al. 2006). However, the precise localization of these two receptors in hypothalamic astroglial cells has not been fully described yet. Cheunsuang \& Morris (2005) have shown the occurrence of the leptin receptor protein in astrocytes in the ARC. Although insulin receptors are expressed by cultured rat astrocytes (Schechter \& Yanovitch 1999), the presence of this receptor in glial cells in situ has never been reported. Insulin binding sites have only been described in freshly isolated human brain tumors of glial origin (Grunberger et al. 1986). Here, we have shown by an immunohistochemical approach that insulin receptors are present in numerous cells in the area bordering the third ventricle (Fig. 2A). We also found that leptin receptors are predominantly located in the ependyma area (Fig. 2B). Consecutive sections hybridized with the DBI probe revealed that in the mouse brain, most of the cells expressing $D B I$ mRNA were also stained with antibodies against insulin or leptin receptors (Fig. 2C and D).

Since acute food deprivation provokes a reduction in plasma insulin and leptin concentrations ( $\mathrm{Bi}$ et al. 2003), these results led us to investigate the effects of i.p. administration of these two hormones on $D B I$ mRNA expression in food-deprived mice. Leptin and insulin had no effect on hypothalamic DBI mRNA levels (Fig. 3A-D). In contrast, insulin, but not leptin, significantly increased $D B I$ mRNA expression in the area bordering the lateral ventricle (Fig. 3E and F). These data suggest that the inhibitory effect of food deprivation on $D B I$ mRNA level in the lateral ventricle area is mediated, at least in part, by a decrease of plasma insulin concentration. There is now clear evidence that the lateral septum, in particular the area bordering the lateral ventricle, is involved in the control of feeding behavior (Pankey et al. 2008, Scopinho et al. 2008). In the lateral septum, dendrites of NPY-expressing neurons penetrate the ependyma to reach the liquor space (Kovacs et al. 2007). Since ODN reduces the level of NPY mRNA in the ARC (Compère et al. 2003, 2005), DBI-derived peptides might also exert an inhibitory effect on NPY neurons in the septum. Thus, these data suggest that extrahypothalamic DBI could be involved in the regulation of energy homeostasis.

In conclusion, we demonstrate for the first time that acute food deprivation markedly reduces $D B I$ mRNA levels in the mouse hypothalamus, and that insulin, but not leptin, stimulates DBI expression in astroglial cells bordering the lateral ventricle. Altogether, these data suggest that DBI-expressing astroglial cells relay hormonal signals from the periphery to the central nervous system.

\section{Declaration of interest}

The authors declare that there is no conflict of interest that could be perceived as prejudicing the impartiality of the research reported.

\section{Funding}

This work was partly supported by an Inserm-FRSQ exchange program (to H Vaudry and G Pelletier) and by the Ministère Français des Affaires Etrangères (to $\mathrm{V}$ Compère). $\mathrm{H}$ Vaudry is Associate Researcher at the Research Center in Molecular Endocrinology, Oncology and Genetics, Laval University, Quebec.

\section{Acknowledgements}

We thank Ms Louise Désy and Johanne Ouellet for their expert technical assistance.

\section{References}

Baskin DG, Breininger JF \& Schwartz MW 1999 Leptin receptor mRNA identifies a subpopulation of neuropeptide $\mathrm{Y}$ neurons activated by fasting in rat hypothalamus. Diabetes 48 828-833.

Bi S, Robinson BM \& Moran TH 2003 Acute food deprivation and chronic food restriction differentially affect hypothalamic NPY mRNA expression. American Journal of Physiology 285 R1030-R1036.

Cheunsuang O \& Morris R 2005 Astrocytes in the arcuate nucleus and median eminence that take up a fluorescent dye from the circulation express leptin receptors and neuropeptide Y Y1 receptors. Glia 52 228-233.

Compère V, Li S, Leprince J, Tonon MC, Vaudry H \& Pelletier G 2003 Effect of intracerebroventricular administration of the octadecaneuropeptide on the expression of pro-opiomelanocortin, neuropeptide $\mathrm{Y}$ and corticotropin-releasing hormone mRNAs in rat hypothalamus. Journal of Neuroendocrinology 15 197-203.

Compère V, Li S, Leprince J, Tonon MC, Vaudry H \& Pelletier G 2005 In vivo action of a new octadecaneuropeptide antagonist on neuropeptide $\mathrm{Y}$ and corticotropin-releasing hormone mRNA levels in rat. Molecular Brain Research 141 156-160.

De Mateos-Verchere JG, Leprince J, Tonon MC, Vaudry H \& Costentin J 2001 The octadecaneuropeptide (diazepam-binding inhibitor (33-50)) exerts potent anorexigenic effects in rodents. European Journal of Pharmacology 414 225-231.

Do Rego JC, Orta MH, Leprince J, Tonon MC, Vaudry H \& Costentin J 2007 Pharmacological characterization of the receptor mediating the anorexigenic action of the octadecaneuropeptide: evidence for an endozepinergic tone regulating food intake. Neuropsychopharmacology 32 1641-1648. 
Grunberger G, Lowe WL Jr, McElduff A \& Glick RP 1986 Insulin receptor of human cerebral gliomas. Structure and function. Journal of Clinical Investigation 77 997-1005.

Hakansson ML, Hulting AL \& Meister B 1996 Expression of leptin receptor mRNA in the hypothalamic arcuate nucleus - relationship with NPY neurones. Neuroreport 7 3087-3092.

Kovacs EG, Szalay F, Racz B \& Halasy K 2007 Chronic fasting-induced changes of neuropeptide $\mathrm{Y}$ immunoreactivity in the lateral septum of intact and ovariectomized female rats. Brain Research 1153 103-110.

Magni P, Vettor R, Pagano C, Calcagno A, Beretta E, Messi E, Zanisi M, Martini L \& Motta M 1999 Expression of a leptin receptor in immortalized gonadotropin-releasing hormone-secreting neurons. Endocrinology 140 1581-1585.

Malagon M, Vaudry H, Van Strien F, Pelletier G, Gracia-Navarro F \& Tonon MC 1993 Ontogeny of diazepam-binding inhibitorrelated peptides (endozepines) in the rat brain. Neuroscience $\mathbf{5 7}$ $777-786$.

Matsuda K, Wada K, Miura T, Maruyama K, Shimakura SI, Uchiyama M, Leprince J, Tonon MC \& Vaudry H 2007 Effect of the diazepambinding inhibitor-derived peptide, octadecaneuropeptide, on food intake in goldfish. Neuroscience 150 425-432.

Niswender KD \& Schwartz MW 2003 Insulin and leptin revisited: adiposity signals with overlapping physiological and intracellular signaling capabilities. Frontiers in Neuroendocrinology 24 1-10.

Pankey EA, Shurley MR \& King BM 2008 A re-examination of septal lesion-induced weight gain in female rats. Physiology and Behavior 93 8-12.
Pardini AW, Nguyen HT, Figlewicz DP, Baskin DG, Williams DL, Kim F \& Schwartz MW 2006 Distribution of insulin receptor substrate-2 in brain areas involved in energy homeostasis. Brain Research 1112 $169-178$.

Schechter R \& Yanovitch T 1999 Insulin effects on extracellular signal regulated kinase cascade in fetal rat astrocyte cell cultures. Neuroscience Letters 268 1-4.

Schwartz MW, Woods SC, Porte D, Seeley RJ \& Baskin DG 2000 Central nervous system control of food intake. Nature 404 661-671.

Scopinho AA, Resstel LB \& Correa FM 2008 al-Adrenoceptors in the lateral septal area modulate food intake behaviour in rats. British Journal of Pharmacology 155 752-756.

Swart I, Jahng JW, Overton JM \& Houpt TA 2002 Hypothalamic NPY AGRP, and POMC mRNA responses to leptin and refeeding in mice. American Journal of Physiology 283 R1020-R1026.

Tonon MC, Désy L, Nicolas P, Vaudry H \& Pelletier G 1990 Immunocytochemical localization of the endogenous benzodiazepine ligand octadecaneuropeptide (ODN) in the rat brain. Neuropeptides 15 17-24.

Volterra A \& Meldolesi J 2005 Astrocytes, from brain glue to communication elements: the revolution continues. Nature Reviews. Neuroscience 6 626-640.

Received in final form 27 January 2010

Accepted 9 March 2010

Made available online as an Accepted

Preprint 10 March 2010 